\title{
Hymenobacter xinjiangensis sp. nov., a radiation- resistant bacterium isolated from the desert of Xinjiang, China
}

\author{
Qiuju Zhang, ${ }^{1}$ Cong Liu, ${ }^{1}$ Yali Tang, ${ }^{1}$ Guoling Zhou, ${ }^{1}$ Ping Shen, ${ }^{1}$ \\ Chengxiang Fang ${ }^{1}$ and Akira Yokota $^{2}$ \\ ${ }^{1}$ College of Life Sciences, Wuhan University, Wuhan 430072, China \\ ${ }^{2}$ Institute of Molecular and Cellular Biosciences, University of Tokyo, Tokyo 113-0032, Japan
}

Correspondence

Chengxiang Fang

cxfang@whu.edu.cn

\begin{abstract}
A Gram-negative, non-motile, rod-shaped and pink-pigmented bacterium, designated strain $\mathrm{X} 2-1 \mathrm{~g}^{\top}$, was isolated from a mixture of sand samples collected from the desert of Xinjiang, China, after exposure of the sand to $8 \mathrm{kGy}$ gamma radiation. Phylogenetic analysis based on $16 \mathrm{~S}$ rRNA gene sequencing indicated that this isolate represents a novel member of the genus Hymenobacter, with low sequence similarities $(<97 \%)$ to recognized Hymenobacter species. Biolog GN2 assays supported this conclusion. Optimum growth was observed at $\mathrm{pH} 7$ and $28^{\circ} \mathrm{C}$. The strain contained MK-7 as the predominant menaquinone and the major fatty acids were iso- $\mathrm{C}_{15: 0}(19.5 \%), \mathrm{C}_{16: 1} \omega 7 c /$ iso- $\mathrm{C}_{15: 0} 2-\mathrm{OH}(20.2 \%), \mathrm{C}_{16: 1} \omega 5 c(10.6 \%), \mathrm{C}_{16: 0}$ $(6.2 \%)$, anteiso- $\mathrm{C}_{17: 1} \mathrm{~B} / \mathrm{iso}-\mathrm{C}_{17: 1} \mathrm{I}(8.5 \%)$ and $\mathrm{C}_{18: 0}(6.5 \%)$. The DNA G+C content was $54 \mathrm{~mol} \%\left(T_{\mathrm{m}}\right)$. On the basis of the polyphasic evidence presented, it is proposed that strain $\mathrm{X} 2-1 \mathrm{~g}^{\top}$ represents a novel species of the genus Hymenobacter, for which the name Hymenobacter xinjiangensis sp. nov. is proposed. The type strain is $\mathrm{X} 2-1 \mathrm{~g}^{\top}$ (=CCTCC AB $206080^{\top}=$ IAM $15452^{\top}$ ).
\end{abstract}

Ionizing-radiation resistance has been observed in several members of the domains Bacteria and Archaea. Among the genera containing ionizing-radiation-resistant organisms, Deinococcus and Rubrobacter show the highest levels of resistance (Rainey et al., 2005). Species of these genera have been shown to survive exposure to doses greater than $25 \mathrm{kGy}$. Other ionizing-radiation-resistant bacteria, although they are less resistant and have been shown to survive after exposure to lower levels of radiation, have also been isolated and described; these include some species of the genera Acinetobacter, 'Chroococcidiopsis', Methylobacterium, Kineococcus, Kocuria and Hymenobacter (Rainey et al., 2005).

At the time of writing, eight species are included in the genus Hymenobacter, namely Hymenobacter roseosalivarius (Hirsch et al., 1998), $H$. actinosclerus (Collins et al., 2000), $H$. aerophilus (Buczolits et al., 2002), H. norwichensis, $H$. ocellatus, H. gelipurpurascens, H. chitinivorans (Buczolits et al., 2006) and $H$. rigui (Baik et al., 2006). Only $H$. actinosclerus has been reported to be resistant to ionizing radiation (Collins et al., 2000). During an investigation of radiotolerant species in the desert of Xinjiang, China, we isolated a Gram-negative, non-motile, rod-shaped, pinkpigmented bacterium. Phylogenetic analysis based on $16 \mathrm{~S}$ rRNA gene sequencing, supported by the results of

The GenBank/EMBL/DDBJ accession number for the 16S rRNA gene sequence of strain $\mathrm{X} 2-1 \mathrm{~g}^{\top}$ is D0888329. polyphasic taxonomic studies, suggested that the newly isolated strain, designated $\mathrm{X} 2-1 \mathrm{~g}^{\mathrm{T}}$, represents a novel species of the genus Hymenobacter.

For isolation of strain X2-1g $\mathrm{g}^{\mathrm{T}}$, sand samples ( $1.0 \mathrm{~g}$ ) collected from the desert were exposed to $8 \mathrm{kGy}$ in a ${ }^{60} \mathrm{Co}$ source at a dose rate of $10 \mathrm{~Gy} \mathrm{~min}^{-1}$ and then suspended in $1.0 \mathrm{ml}$ sterile water and homogenized for $5 \mathrm{~min}$ in a sterile mortar. The resulting supernatant was spread on $0.1 \times$ trypticase soy agar (TSA) (Chanal et al., 2006), and isolation was achieved after 7 days incubation at $30{ }^{\circ} \mathrm{C}$. The isolate was routinely cultured on the same medium and stored as a glycerol suspension $(20 \%, \mathrm{w} / \mathrm{v})$ at $-80{ }^{\circ} \mathrm{C}$.

Extraction of genomic DNA, PCR amplification of the $16 \mathrm{~S}$ rRNA gene and sequencing of the purified PCR product were carried out according to the methods of Lin et al. (2004). Phylogenetic analysis was performed by using MEGA, version 3.1 (Kumar et al., 2004), after multiple alignment of the data via CLUSTAL_X (Thompson et al., 1997). Distances were obtained using options according to the Kimura two-parameter model (Kimura, 1980) and clustering was performed by using the neighbour-joining method (Saitou \& Nei, 1987). Bootstrap values from 1000 replications were used to determine the confidence level of the branches (Felsenstein, 1985).

Analysis of the 16S rRNA gene sequence of strain X2-1g resulted in a sequence of 1407 bases. Sequence similarities 
to recognized members of the genus Hymenobacter were below the threshold for demarcating bacterial species, as follows: H. rigui WPCB $131^{\mathrm{T}}$ (96.7\%), H. gelipurpurascens $\operatorname{Txg}^{\mathrm{T}}(95.1 \%), H$. chitinivorans $\operatorname{Txcl}^{\mathrm{T}}(95.0 \%), H$. norwichensis NS/50 ${ }^{\mathrm{T}}$ (94.5\%), H. actinosclerus CCUG $39621^{\mathrm{T}}(94.3 \%), H$. roseosalivarius AA-718 ${ }^{\mathrm{T}}(93.7 \%), H$. aerophilus $\mathrm{I} / 26-\mathrm{Cor}^{\mathrm{T}}(93.4 \%)$ and $H$. ocellatus $\mathrm{Txol}^{\mathrm{T}}$ (93.4\%). No other recognized bacterial species showed more than $90 \% 16 \mathrm{~S}$ rRNA gene sequence similarity to the new isolate. This relationship between strain $\mathrm{X} 2-\mathrm{lg}^{\mathrm{T}}$ and other members of the genus Hymenobacter is also evident in the phylogenetic tree. As shown in Fig. 1, strain X2-1g clustered with species of the genus Hymenobacter, but $K_{\text {nuc }}$ values clearly differentiated the novel strain from recognized species. Therefore, $16 \mathrm{~S}$ rRNA gene sequence similarity data and phylogenetic analysis suggest that strain $\mathrm{X} 2-1 \mathrm{~g}^{\mathrm{T}}$ represents a novel species in the genus Hymenobacter.

Gram behaviour was investigated by the $\mathrm{KOH}$-lysis test (Moaledji, 1986) and by staining as described by Smibert \& Krieg (1994). Cell morphology, size and motility were examined by phase-contrast microscopy (Olympus) from PYES cultures (Buczolits et al., 2002) of different growth stages. Growth at different temperatures $(4,28,37$ and $\left.42{ }^{\circ} \mathrm{C}\right), \mathrm{pH}(4-10)$ and $\mathrm{NaCl}$ concentration $(0,1,2,4$ and $10 \%, w / v)$ was investigated on PYES agar for up to 1 week. Conventional biochemical tests were performed as described by Smibert \& Krieg (1994), including tests for oxidase, catalase, nitrate reduction, $\mathrm{H}_{2} \mathrm{~S}$ production, citrate utilization, indole production and urease. Additional phenotypic characteristics were determined by using the Biolog microbial identification system following the

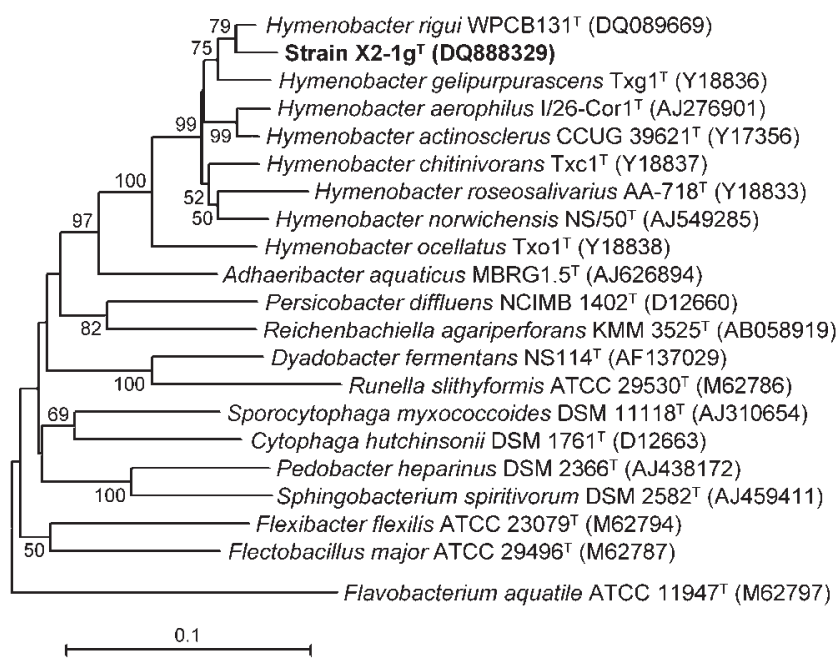

Fig. 1. Neighbour-joining tree based on nearly complete $16 \mathrm{~S}$ rRNA gene sequences showing the phylogenetic position of strain $\mathrm{X} 2-1 \mathrm{~g}^{\top}$. Bootstrap values, expressed as percentages of 1000 replications, are given at branching points. Flavobacterium aquatile ATCC $11947^{\top}$ was used as an outgroup. Bar, $10 \%$ sequence divergence. protocol provided by the manufacturer. Enzyme activities were tested by using the API ZYM kit (bioMérieux) following the manufacturer's instructions. Antimicrobial susceptibility testing and pigment analysis were performed according to the method of Buczolits et al. (2002). The following antibiotics were tested: chloramphenicol $(30 \mu \mathrm{g})$, colistin sulfate $(10 \mu \mathrm{g})$, erythromycin $(15 \mu \mathrm{g})$, gentamicin $(10 \mu \mathrm{g})$, kanamycin $(30 \mu \mathrm{g})$, penicillin $\mathrm{G}(10 \mathrm{IU})$, bacitracin (10 IU), polymyxin B sulfate (300 IU), tetracycline $(10 \mu \mathrm{g})$ and vancomycin $(30 \mu \mathrm{g})$. Any sign of growth inhibition was scored as sensitivity to that antibiotic. Resistance to an antimicrobial drug was indicated if no inhibition zone was observed. To determine the survival rate after exposure to gamma radiation, cultures were grown to an $\mathrm{OD}_{600}$ of about 0.5 , irradiated at the desired dose, diluted serially and plated (de Groot et al., 2005). Percentage survival was determined by comparing against unirradiated cultures.

The $\mathrm{G}+\mathrm{C}$ content of the genomic DNA was determined according to the thermal denaturation $\left(T_{\mathrm{m}}\right)$ method (Marmur \& Doty, 1962). The respiratory quinone system was extracted and determined by HPLC (Shimadzu) as described by Xie \& Yokota (2003). Cellular fatty acids of strain $\mathrm{X} 2-1 \mathrm{~g}^{\mathrm{T}}$ were analysed as methyl esters by GC (Hewlett Packard 6890) according to the instructions of the Sherlock Microbial Identification System (MIDI).

The physiological and biochemical characteristics of strain $\mathrm{X} 2-1 \mathrm{~g}^{\mathrm{T}}$ are listed in the species description below and in Table 1. The phenotypic features that can be used to differentiate strain $\mathrm{X} 2-1 \mathrm{~g}^{\mathrm{T}}$ from its close relatives within the genus Hymenobacter are given in Table 1. The results of phenotypic examination demonstrated that the strain studied has many traits in common with $H$. rigui. However, the habitats occupied by these two taxa are different: $H$. rigui lives in freshwater (Baik et al., 2006), whereas strain $\mathrm{X} 2-1 \mathrm{~g}^{\mathrm{T}}$ was isolated from desert sand samples. In contrast to $H$. rigui, strain $\mathrm{X} 2-1 \mathrm{~g}^{\mathrm{T}}$ tolerated high doses of gamma radiation, utilized D-mannitol, failed to assimilate D-glucose and was unable to grow at $1 \% \mathrm{NaCl}$ or high $\mathrm{pH}$. Furthermore, the genomic $\mathrm{G}+\mathrm{C}$ content of $\mathrm{X} 2-\mathrm{gg}^{\mathrm{T}}(54 \mathrm{~mol} \%)$ was much lower than that of H. rigui (65 mol\%). Differences were also observed in the cellular fatty acid compositions of the novel strain and strains of recognized Hymenobacter species, such as the presence of $\mathrm{C}_{18: 0}$ and $\mathrm{C}_{18: 1} \omega 7 \mathrm{c}$ fatty acids and some quantitative differences in certain components (Table 2).

It is therefore evident from its phylogenetic distinctness in combination with differences in cellular fatty acid composition and phenotypic findings that strain $\mathrm{X} 2-\mathrm{gg}^{\mathrm{T}}$ can be differentiated from its nearest neighbours. Thus, the results of the polyphasic analysis presented here demonstrate that the bacterium studied could not be assigned to any of the currently described species of the genus Hymenobacter, and support the placement of strain $\mathrm{X} 2-1 \mathrm{~g}^{\mathrm{T}}$ in a novel species, for which the name Hymenobacter xinjiangensis sp. nov. is proposed. 
Table 1. Differential characteristics among Hymenobacter type strains

Strains: 1, X2-1g ${ }^{\mathrm{T}}$; 2, H. norwichensis $\mathrm{LMG} 21876^{\mathrm{T}}$; 3, H. rigui IMSNU $14116^{\mathrm{T}}$; 4, H. actinosclerus CCUG $39621^{\mathrm{T}}$; 5, H. aerophilus LMG $19657^{\mathrm{T}} ;$ 6, H. roseosalivarius DSM $11622^{\mathrm{T}}$. Data were taken from Hirsch et al. (1998), Collins et al. (2000), Buczolits et al. (2002, 2006), Baik et al. (2006) and this study. +, Positive; -, negative; $(+)$, weakly positive; ND, no data available.

\begin{tabular}{|c|c|c|c|c|c|c|}
\hline Characteristic & 1 & 2 & 3 & 4 & 5 & 6 \\
\hline Pigmentation & Pink & Brick red & Pinkish red & Red & Red & Reddish \\
\hline \multicolumn{7}{|l|}{ Growth at/in: } \\
\hline $4{ }^{\circ} \mathrm{C}$ & + & $(+)$ & + & - & + & + \\
\hline $28{ }^{\circ} \mathrm{C}$ & + & + & + & + & + & - \\
\hline $37{ }^{\circ} \mathrm{C}$ & $(+)$ & - & + & + & - & - \\
\hline $42{ }^{\circ} \mathrm{C}$ & - & - & - & + & - & - \\
\hline $1 \% \mathrm{NaCl}$ & - & - & + & $\mathrm{ND}$ & + & + \\
\hline $3 \% \mathrm{NaCl}$ & - & - & - & $\mathrm{ND}$ & $(+)$ & - \\
\hline $\mathrm{pH}$ for growth & $5-7$ & ND & $5-11$ & ND & ND & ND \\
\hline \multicolumn{7}{|c|}{ Biolog GN2 plate substrate response for: } \\
\hline Aesculin & + & $\mathrm{ND}$ & $(+)$ & - & - & - \\
\hline$N$-Acetyl-D-glucosamine & $(+)$ & - & - & $(+)$ & - & - \\
\hline Arbutin & - & $(+)$ & - & + & - & - \\
\hline D-Fructose & $(+)$ & $(+)$ & + & - & + & - \\
\hline D-Glucose & - & $(+)$ & + & + & + & - \\
\hline D-Mannose & $(+)$ & $(+)$ & - & + & + & - \\
\hline Sucrose & + & - & + & - & $(+)$ & - \\
\hline D-Galactose & $(+)$ & $(+)$ & + & - & - & - \\
\hline Maltose & + & $(+)$ & + & - & - & - \\
\hline D-Mannitol & + & $(+)$ & - & - & - & - \\
\hline \multicolumn{7}{|l|}{ Enzyme activity (API ZYM): } \\
\hline Cystine arylamidase & $(+)$ & - & $(+)$ & + & $\mathrm{ND}$ & ND \\
\hline$\alpha$-Glucosidase & - & - & + & ND & $\mathrm{ND}$ & + \\
\hline DNA G + C content $(\mathrm{mol} \%)$ & 54 & ND & 65 & 62 & 63 & 56 \\
\hline
\end{tabular}

\section{Description of Hymenobacter xinjiangensis sp. nov.}

Hymenobacter xinjiangensis (xin.jiang.en'sis. N.L. masc. adj. xinjiangensis pertaining to Xinjiang, an autonomous region in north-west China).

Cells are Gram-negative, aerobic, non-spore-forming rods. Motility is not observed. Cells are approximately $0.7 \times 2-$ $5 \mu \mathrm{m}$ in size. Cells grow best on nutrient-reduced media such as $0.1 \times$ TSA and PYES agar. Colonies on $0.1 \times$ TSA and PYES agar are translucent, pink, circular, entire, of low convexity and rough; colony diameter is up to $1.5 \mathrm{~cm}$ after 5 days at $28{ }^{\circ} \mathrm{C}$. The temperature range for growth is 4 $37{ }^{\circ} \mathrm{C}$ (optimum $28{ }^{\circ} \mathrm{C}$ ). Oxidase- and catalase-positive. Aesculin hydrolysis is positive. Negative for fermentation of glucose, nitrate reduction, $\mathrm{H}_{2} \mathrm{~S}$ production, citrate utilization, indole production and urease. In the API ZYM system, alkaline phosphatase, esterase C4, esterase lipase C8, leucine arylamidase, valine arylamidase, cystine arylamidase, acid phosphatase, naphthol-AS-BI-phosphohydrolase, $N$ acetyl- $\beta$-glucosaminidase and $\alpha$-mannosidase activity are detectable. Lipase C14, trypsin, chymotrypsin, $\alpha$-galactosidase, $\beta$-galactosidase, $\beta$-glucuronidase, $\alpha$-glucosidase, $\beta$-glucosidase and $\alpha$-fucosidase activity are not detectable. Positive in the Biolog system for dextrin, D-cellobiose, ierythritol, L-fucose, lactulose, maltose, D-mannitol, Dpsicose, D-sorbitol, sucrose, D-trehalose, acetic acid, D-galacturonic acid, D-gluconic acid, D-glucosaminic acid, $\gamma$-hydroxybutyric acid, propionic acid, succinic acid, glucuronamide, L-alanine, glycyl L-glutamic acid, L-serine, DL-carnitine, thymidine and $\alpha$-D-glucose 1-phosphate. Negative in the Biolog system for $\alpha$-cyclodextrin, Tweens 40 and 80, $N$-acetyl-D-galactosamine, adonitol, L-arabinose, D-arabitol, gentiobiose, $\alpha$-D-glucose, $\alpha$-Dlactose, methyl $\beta$-D-glucoside, pyruvic acid methyl ester, succinic acid methyl ester, cis-aconitic acid, citric acid, formic acid, D-galactonic acid lactone, $\alpha$-hydroxybutyric acid, $\beta$-hydroxybutyric acid, $p$-hydroxyphenylacetic acid, itaconic acid, $\alpha$-ketobutyric acid, $\alpha$-ketoglutaric acid, $\alpha$ ketovaleric acid, DL-lactic acid, malonic acid, quinic acid, sebacic acid, bromosuccinic acid, succinamic acid, Lalaninamide, L-alanyl glycine, L-asparagine, glycyl Laspartic acid, L-histidine, hydroxy-L-proline, L-leucine, L-ornithine, L-phenylalanine, L-proline, L-pyroglutamic acid, D-serine, L-threonine, $\gamma$-aminobutyric acid, urocanic acid, inosine, uridine, phenylethylamine, putrescine, 
Table 2. Fatty acid profile of strain $X 2-1 g^{\top}$ compared with other members of the genus Hymenobacter

Strains: $1, \mathrm{X} 2-1 \mathrm{~g}^{\mathrm{T}} ; 2$, H. norwichensis LMG $21876^{\mathrm{T}} ; 3$, H. rigui IMSNU $14116^{\mathrm{T}} ; 4$, H. actinosclerus CCUG $39621^{\mathrm{T}} ; 5, H$. aerophilus LMG $19657^{\mathrm{T}}$; 6, H. roseosalivarius DSM $11622^{\mathrm{T}}$. Values are percentages of total fatty acids. Data were taken from Hirsch et al. (1998), Collins et al. (2000), Buczolits et al. (2002, 2006), Baik et al. (2006) and this study. tr, Trace $(<1 \%)$; ND, not detected/not reported.

\begin{tabular}{|c|c|c|c|c|c|c|}
\hline Fatty acid & 1 & 2 & 3 & 4 & 5 & 6 \\
\hline $\mathrm{C}_{14: 0}$ & 1.3 & 1.3 & $\mathrm{ND}$ & $\mathrm{ND}$ & $\mathrm{ND}$ & $\mathrm{ND}$ \\
\hline iso- $\mathrm{C}_{15: 1} \mathrm{G}$ & 2.0 & ND & $\mathrm{ND}$ & $\mathrm{ND}$ & $\mathrm{ND}$ & ND \\
\hline Summed feature $2^{\star}$ & 2.2 & $\operatorname{tr}$ & $\mathrm{ND}$ & 2.3 & $\operatorname{tr}$ & ND \\
\hline iso- $\mathrm{C}_{15: 0}$ & 19.5 & 27.3 & 34.8 & 22.3 & 10.8 & 8.3 \\
\hline anteiso- $\mathrm{C}_{15: 0}$ & 3.7 & 10.6 & 5.9 & 25.8 & 22.3 & ND \\
\hline iso- $\mathrm{C}_{16: 1} \mathrm{H}$ & 1.8 & 1.4 & $\mathrm{ND}$ & 1.5 & 1.5 & 2.7 \\
\hline iso- $\mathrm{C}_{16: 0}$ & 1.0 & 1.2 & $\mathrm{ND}$ & $\mathrm{ND}$ & $\operatorname{tr}$ & 2.1 \\
\hline Summed feature $3^{*}$ & 20.2 & 23.6 & 13.8 & 13.1 & 21.4 & 29.8 \\
\hline $\mathrm{C}_{16: 1} \omega 5 c$ & 10.6 & 13.6 & 15.0 & 3.7 & 7.9 & 23.3 \\
\hline $\mathrm{C}_{16: 0}$ & 6.2 & 2.2 & 6.4 & $\mathrm{ND}$ & 1.7 & 1.1 \\
\hline iso- $\mathrm{C}_{15: 0} 3-\mathrm{OH}$ & 2.2 & 2.2 & $\mathrm{ND}$ & 1.6 & 1.6 & 2.7 \\
\hline Summed feature $4^{*}$ & 8.5 & 8.3 & 14.4 & 19.9 & 17.7 & 18.5 \\
\hline iso- $\mathrm{C}_{17: 0} 3-\mathrm{OH}$ & 3.4 & 3.0 & 3.1 & 3.1 & 3.5 & 5.8 \\
\hline iso- $\mathrm{C}_{17: 0}$ & 1.8 & 1.6 & 5.0 & 1.8 & 4.5 & 1.7 \\
\hline anteiso- $\mathrm{C}_{17: 0}$ & $\operatorname{tr}$ & ND & $\mathrm{ND}$ & $\operatorname{tr}$ & 2.3 & ND \\
\hline $\mathrm{C}_{17: 0} 2-\mathrm{OH}$ & $\operatorname{tr}$ & ND & $\mathrm{ND}$ & 2.0 & 1.3 & ND \\
\hline $\mathrm{C}_{18: 1} \omega 9 \mathrm{c}$ & 1.1 & ND & $\mathrm{ND}$ & ND & ND & ND \\
\hline $\mathrm{C}_{18: 0}$ & 6.5 & ND & $\mathrm{ND}$ & $\mathrm{ND}$ & ND & ND \\
\hline $\mathrm{C}_{18: 1} \omega 7 c$ & 4.8 & ND & $\mathrm{ND}$ & $\mathrm{ND}$ & ND & ND \\
\hline
\end{tabular}

*Summed feature 2 contains $\mathrm{C}_{13: 0} 3-\mathrm{OH}$ and/or iso- $\mathrm{C}_{15: 1} \mathrm{I}$; summed feature 3 contains $\mathrm{C}_{16: 1} \omega 7 c$ and/or iso- $\mathrm{C}_{15: 0} 2-\mathrm{OH}$; summed feature 4 contains anteiso- $\mathrm{C}_{17: 1} \mathrm{~B}$ and/or iso- $\mathrm{C}_{17: 1} \mathrm{I}$.

2-aminoethanol, 2,3-butanediol and glycerol. Sensitive to chloramphenicol, colistin sulfate, erythromycin, gentamicin, penicillin $G$, polymyxin $B$ sulfate, tetracycline and vancomycin. Tolerates high doses of gamma radiation, with a $D_{10}$ (dose required to reduce the bacterial population by 10 -fold) of $4.8 \mathrm{kGy}$. Quinone system is menaquinone MK-7. Major fatty acids $(>5 \%)$ are iso$\mathrm{C}_{15: 0} \quad(19.5 \%), \quad \mathrm{C}_{16: 1} \omega 7 c /$ iso- $\mathrm{C}_{15: 0} \quad 2-\mathrm{OH} \quad(20.2 \%)$, $\mathrm{C}_{16: 1} \omega 5 c(10.6 \%), \mathrm{C}_{16: 0}(6.2 \%)$, anteiso- $\mathrm{C}_{17: 1} \mathrm{~B} /$ iso$\mathrm{C}_{17: 1}$ I $(8.5 \%)$ and $\mathrm{C}_{18: 0}(6.5 \%)$; complete fatty acid data are given in Table 2. The $\mathrm{G}+\mathrm{C}$ content of the type strain is $54 \mathrm{~mol} \%\left(T_{\mathrm{m}}\right)$.

The type strain, X2-1g ${ }^{\mathrm{T}}$ (=CCTCC AB $206080^{\mathrm{T}}=\mathrm{IAM}$ $\left.15452^{\mathrm{T}}\right)$, was isolated from gamma-irradiated soil of the Xinjiang desert, China.

\section{Acknowledgements}

We are grateful to J. P. Euzéby for his help with nomenclature and etymology.

\section{References}

Baik, K. S., Seong, C. N., Moon, E. Y., Park, Y.-D., Yi, H. \& Chun, J. (2006). Hymenobacter rigui sp. nov., isolated from wetland freshwater. Int J Syst Evol Microbiol 56, 2189-2192.

Buczolits, S., Denner, E. B. M., Vybiral, D., Wieser, M., Kämpfer, P. \& Busse, H.-J. (2002). Classification of three airborne bacteria and proposal of Hymenobacter aerophilus sp. nov. Int J Syst Evol Microbiol 52, 445-456.

Buczolits, S., Denner, E. B. M., Kämpfer, P. \& Busse, H.-J. (2006). Proposal of Hymenobacter norwichensis sp. nov., classification of 'Taxeobacter ocellatus', 'Taxeobacter gelupurpurascens' and 'Taxeobacter chitinovorans' as Hymenobacter ocellatus sp. nov., Hymenobacter gelipurpurascens sp. nov. and Hymenobacter chitinivorans sp. nov., respectively, and emended description of the genus Hymenobacter Hirsch et al. 1999. Int J Syst Evol Microbiol 56, 2071-2078.

Chanal, A., Chapon, V., Benzerara, K., Barakat, M., Christen, R., Achouak, W., Barras, F. \& Heulin, T. (2006). The desert of Tataouine: an extreme environment that hosts a wide diversity of microorganisms and radiotolerant bacteria. Environ Microbiol 8, 514-525.

Collins, M. D., Hutson, R. A., Grant, I. R. \& Patterson, M. F. (2000). Phylogenetic characterization of a novel radiation-resistant bacterium from irradiated pork: description of Hymenobacter actinosclerus sp. nov. Int J Syst Evol Microbiol 50, 731-734.

de Groot, A., Chapon, V., Servant, P., Christen, R., Saux, M. F.-L., Sommer, S. \& Heulin, T. (2005). Deinococcus deserti sp. nov., a gamma-radiation-tolerant bacterium isolated from the Sahara Desert. Int J Syst Evol Microbiol 55, 2441-2446.

Felsenstein, J. (1985). Confidence limits on phylogenies: an approach using the bootstrap. Evolution 39, 783-791.

Hirsch, P., Ludwig, W., Hethke, C., Sittig, M., Hoffmann, B. \& Gallikowski, C. A. (1998). Hymenobacter roseosalivarius gen. nov., sp. nov. from continental Antarctic soils and sandstone: bacteria of the Cytophaga/Flavobacterium/Bacteriodes line of phylogenetic descent. Syst Appl Microbiol 21, 374-383.

Kimura, M. (1980). A simple method for estimating evolutionary rates of base substitutions through comparative studies of nucleotide sequences. J Mol Evol 16, 111-120.

Kumar, S., Tamura, K. \& Nei, M. (2004). MEGA 3: integrated software for molecular evolutionary genetics analysis and sequence alignment. Brief Bioinform 5, 150-163.

Lin, Y.-C., Uemori, K., de Briel, D. A., Arunpairojana, V. \& Yokota, A. (2004). Zimmermannella helvola gen. nov., sp. nov., Zimmermannella alba sp. nov., Zimmermannella bifida sp. nov., Zimmermannella faecalis sp. nov. and Leucobacter albus sp. nov., novel members of the family Microbacteriaceae. Int J Syst Evol Microbiol 54, 1669-1676.

Marmur, J. \& Doty, P. (1962). Determination of the base composition of deoxyribonucleic acid from its thermal denaturation temperature. $J$ Mol Biol 5, 109-118.

Moaledji, K. (1986). Comparison of Gram-staining and alternate methods, $\mathrm{KOH}$ test and aminopeptidase activity in aquatic bacteria: their application to numerical taxonomy. J Microbiol Methods 5, 303-310.

Rainey, F. A., Ray, K., Ferreira, M., Gatz, B. Z., Nobre, M. F., Bagaley, D., Rash, B. A., Park, M. J., Earl, A. M. \& other authors (2005). Extensive diversity of ionizing-radiation-resistant bacteria recovered from Sonoran Desert soil and description of nine new species of the genus Deinococcus obtained from a single soil sample. Appl Environ Microbiol 71, 5225-5235. 
Saitou, N. \& Nei, M. (1987). The neighbor-joining method: a new method for reconstructing phylogenetic trees. Mol Biol Evol 4, 406-425.

Smibert, R. M. \& Krieg, N. R. (1994). Phenotypic characterization. In Methods for General and Molecular Bacteriology, pp. 607-654. Edited by P. Gerhardt, R. G. E. Murray, W. A. Woods \& N. R. Krieg. Washington, DC: American Society for Microbiology.
Thompson, J. D., Gibson, T. J., Plewniak, F., Jeanmougin, F. \& Higgins, D. G. (1997). The CLUSTAL_X windows interface: flexible strategies for multiple sequence alignment aided by quality analysis tools. Nucleic Acids Res 25, 4876-4882.

Xie, C. H. \& Yokota, A. (2003). Phylogenetic analysis of Lampropedia hyalina based on the 16S rRNA gene sequence. J Gen Appl Microbiol 49, 345-349. 